\title{
Floristic study of bryophytes in Hangyeong Gotjawal (Cheongsu-ri), Jejudo Island
}

\author{
Eun-Young YIM*, Byoung-Ki CHOI and Hwa-Ja HYUN \\ Warm Temperate and Subtropical Forest Research Center, National Institute of Forest Science, Seogwipo 63582, Korea \\ (Received 2 September 2019; Revised 29 September 2019; Accepted 30 September 2019)
}

\begin{abstract}
Recently, it has become known that Gotjawal terrain is an important area, therefore the study on this area has conducted in the geological, ecological, and cultural aspects. The studies on bryophytes of Gotjawal, however, have not been sufficiently performed. This study presents a survey on the bryophytes of the evergreen broad-leaved forest of Cheongsu-ri at Hangyeong Gotjawal in the southwestern part of Jejudo Island, Korea. A total of 72 taxa belonging to the Bryophyta (18 families 43 genera 55 species) and Marchantiophyta (11 families 13 genera 17 species) were determined and the liverwort index was $23.6 \%$. Predominant life-form was weft. The rates of the bryophytes dominating in mesic to hygric sites were higher than the bryophytes mainly observed in xeric habitats. These values indicate that the forests are widespread and dense in this study area. Upon an investigation of the substrates, the bryophytes on rocks were most diverse. The results appear to stem from the fact that volcanic rock masses of various sizes lay scattered over the study area, offering numerous micro-habitats for bryophyte due to one of the characteristics of Gotjawal. We suggest that more detailed studies should be conducted at the regional scale to establish the bryophyte flora of Gotjawal and the evergreen broad-leaved forests on Jejudo Island.
\end{abstract}

Keywords: bryophyte, Hangyeong Gotjawal, liverwort index, life-form

Jejudo Island was formed by volcanic activities and has the unique topological and geological features. In this unique volcanic terrain, forests established on lava flow are scattered around the island, known as "Gotjawal," which is a newly coined compound word and comes from dialects spoken on Jejudo Island (Jeju Special Self-Governing Province, 2009; Yoon, 2014). It is difficult to access Gotjawal and use it for agricultural purpose, as the trees and vines are dense, rocks of various sizes are scattered randomly, and the depth of soil is shallow in Gotjawal. Therefore, thus far it has only been used for grazing cattle, making charcoal or as a firewood source and is commonly recognized as useless land (Jeon et al., 2012; Jeong, 2012, 2015; Yoon, 2014). Recently, however, it has become known that Gotjawal is an area inhabited by various plants and animals where unique and various ecosystems are also sustained; the area serves as a natural waterway of the type necessary to create underground water, and it has high preservation values (Jeon et al., 2012; Kang et al., 2013; Yoon, 2014; Jeong, 2015). In addition, its cultural importance has also emerged. Therefore, the scientific studies of Gotjawal have been conducted to examine geological, ecological, and cultural aspects (Jeong et al., 2013; Jeon et al., 2015). However, a floristic study of bryophytes has not been conducted, except for that Dongbaek-dongsan at Seonheul Gotjawal in the northeastern part by Yim et al. (2013) and Subtropical Forest of Nabeup-ri at Aewol Gotjawal in the southwestern part by Yim and Hyun (2018).

The area and range of Gotjawal terrain have not been yet established (Jeon et al., 2015). According to Song (2000), Gotjawal can be divided into four major terrains, i.e., GujwaSeongsan, Jocheon-Hamdeok, Hangyeong-Andeok, and Aewol. Among them, Hangyeong-Andeok Gotjawal terrain is divided into Doneori Gotjawal lava flow and Byeongak Gotjawal lava flow. Doneori Gotjawal lava flow begun from

*Author for correspondence: curie580@korea.kr 
the vicinity of Doneri Oreum (439 $\mathrm{m}$ above sea level) and branched off into Wollyeong-ri, Hallim-eup and Yeongnakri, Daejeong-eup. Its flow distance is $12.5 \mathrm{~km}$, which is longest of the Gotjawal lava flows. Byeongak Gotjawal lava flow was erupted from Byeongak Oreum (418 m above sea level). The distance is $9 \mathrm{~km}$ and wide is $2-3 \mathrm{~km}$ (Song, 2003a, 2003b).

The evergreen broad-leaved forest of Cheongsu-ri, which is a branch of Doneori Gotjawal lava flow of Hangyeong-Andeok Gotjawal terrain located in the southwestern part of Jejudo Island, is also known as Sanyang Gotjawal. This area consists of dense evergreen broad-leaved forests where Quercus glauca Thunb., Castanopisis sieboldii (Makino) Hatus., Neolitsea sericea (Blume) Koidz., and Machilus japonica Siebold \& Zucc. etc. are distributed on thwide rock fields. In addition, various ferns such as Asplenium ritoense Hayata and A. varians Wall. ex Hook. \& Grev. etc. are inhabit and form a unique landscape. The rare plants, Maesa japonica (Thunb.) Moritzi \& Zoll. and Neocheiropteris ensata (Thunb.) Ching etc. are also inhabit. M. japonica is an evergreen shrub recently reported as unrecorded plants (Moon et al., 2006), and are known to be distributed only in this area and its environs. In addition, $N$. ensata forms the largest population in Korea. From these reasons, this area is considered very important region from an academic point of view. The area is adjacent to the village, and has been damaged by the grazing cattle, making charcoal, or as a firewood source in the past. The vegetation is currently restored. Plants, animals, and stones etc., however, can be collected without permission due to its easy access. Moreover, since it is managed jointly by the village, there is a possibility of serious damage if conservation measures are not taken. Therefore, it is necessary to investigate natural resources to enhance the value of the area, come up with specific management measures for the preservation of species and natural habitat, and induce the development of the area as an ecotourism destination that also contributes to improving the income level of local residents.

The purpose of this study was to establish a bryophyte flora of the evergreen broad-leaved forest of Cheongsu-ri at Hangyeong Gotjawal. Furthermore, this study aims to contribute to studies of the bryophyte flora of Gotjawal and the evergreen broad-leaved forests on Jejudo Island on a regional scale and to provide basic data for selecting relevant indicator species.

\section{Materials and Methods}

\section{Field surveys}

Field surveys were carried out in the evergreen broad-leaved forest of Cheongsu-ri at Hangyeong Gotjawal with an area of approximately $501,223 \mathrm{~m}^{2}$ (Fig. 1), a total of 7 times from August 2011 to September 2018.

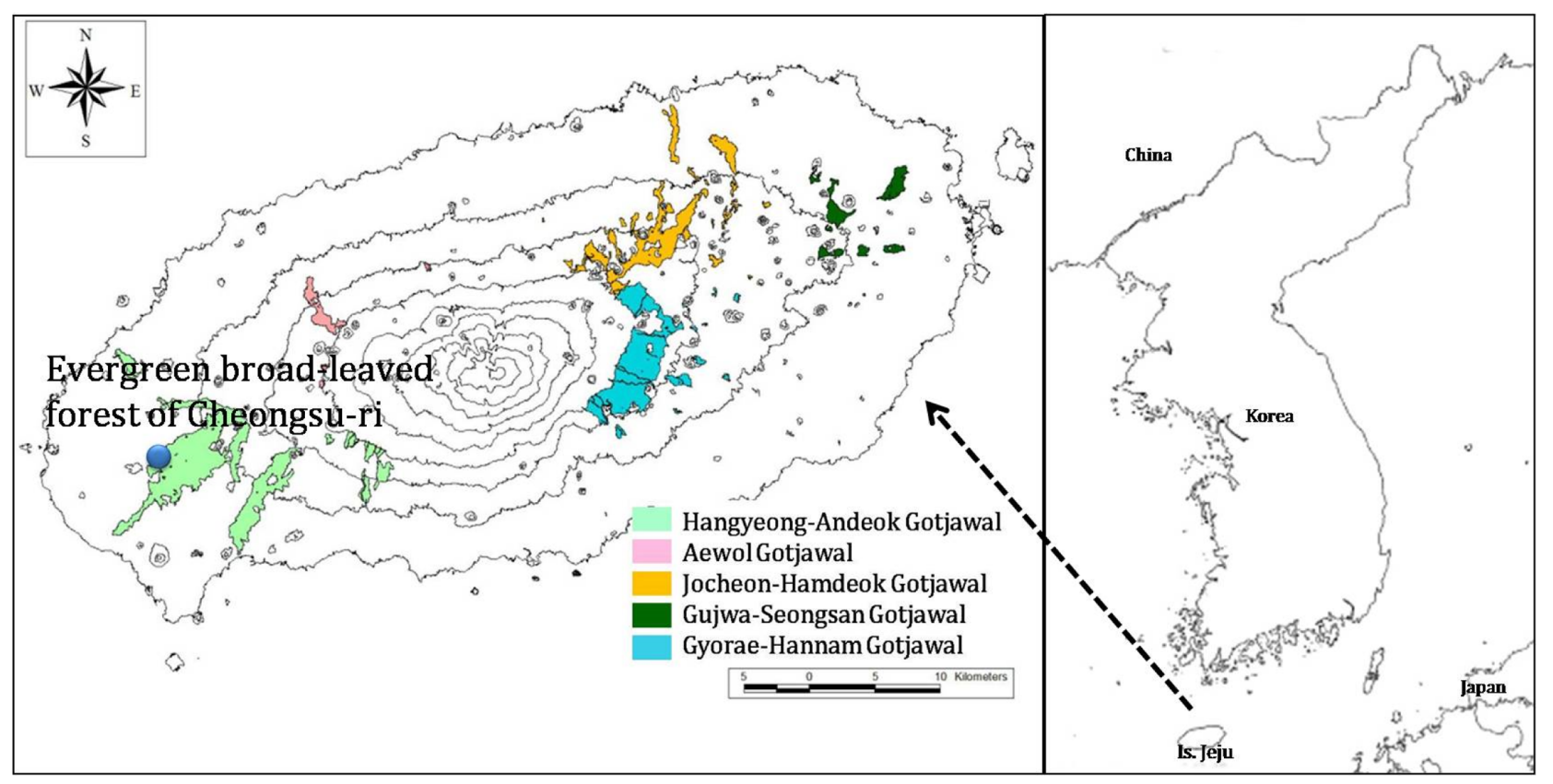

Fig. 1. The map showing the location of Evergreen broad-leaved forest of Cheongsu-ri and distribution of Gotjawal terrain, Jejudo Island, Korea. Gotjawal terrain designated by the Jeju Special Self-Governing Province (1997) are represented by colored areas. 


\section{Identification, nomenclature, and arrangement of taxa}

The samples collected in the investigated area were identified at species level with macroscopic morphology and microscopic features using relevant literatures (Iwatsuki and Mizutani, 1972; Inoue, 1974, 1976; Choe, 1980; Noguchi, 1987, 1988, 1989, 1991, 1994; Gao et al., 1999; Iwatsuki, 2001; Li et al., 2001; Wu et al., 2002; Cao et al., 2003). The voucher specimens were deposited in Warm Temperate and Subtropical Forest Research Center in Korea (WFRC). Only one collection number for each taxon were cited to avoid repetition in the floristic list. The nomenclature and arrangement of taxa are followed the system which is proposed by Goffinet et al. (2009) and Crandall-Stotler et al. (2009) for the mosses and liverworts respectively.

\section{Life-forms and substrates}

The life-forms of bryophytes in the study area have been estimated using Mägdefrau (1982), and also they are given in the floristic list for each taxon. The records of substrates for each taxon were included in this list.

\section{Number of bryophyte taxa and liverwort index}

We compared the number of taxa and liverwort index of the evergreen broad-leaved forest of Cheongsu-ri at Hangyeong Gotjawal with other localities based on revealed literatures [i.e., Taebaeksan Mt. (Papp, 2008), Deogyusan Mt. (Choi et al., 2010; Yoon et al., 2011), Dongbaekdongsan (Yim et al., 2013), Gayasan Mt. (Sin, 2016a), Sobaeksan Mt. (Sin, 2016b), and Subtropical Forest of Nabeup-ri (Yim and Hyun, 2018)]. The liverwort index, which is based on the character that the liverworts and hornworts tend to prefer more humid conditions than mosses, was calculated as follow (Nakanishi, 2001):
Liverwort index $(\%)=\frac{\text { No. of liverworts }+ \text { No. of hornworts }}{\text { The total No. of bryophytes }} \times 100$

\section{Results and Discussion}

\section{The number of taxa and liverwort index}

In this study, a total of 72 taxa belonging to the Bryophyta (18 families 43 genera 55 species) and Marchantiophyta (11 families 13 genera 17 species) were determined (Appendix 1).

The comparison result for the number of taxa presented that evergreen broad-leaved forest of Cheongsu-ri at Hangyeong Gotjawal contained rich diversity of bryophytes for the area (Table 1). This is one of the characteristics of Gotjawal area, which is highly biodiversity despite its narrow area and altitude above sea level range.

The liverwort index, which is based on the character that the liverworts and hornworts tend to prefer more humid conditions than mosses. Therefore, it is useful to compare air humidity between different sites (Nakanishi, 2001). The liverwort index of the evergreen broad-leaved forest of Cheongsu-ri was $23.6 \%$ and this value indicates that the air humidity of investigated area was relatively lower than Sobaeksan Mt. (41.9\%), Deogyusan Mt. (40.8\%), Gayasan Mt. (37.6\%), Subtropical Forest of Nabeupri (30.2\%), Taebaeksan Mt. (29.2\%), and Dongbaek-dongsan $(27.0 \%)$ (Table 1). The liverwort index of the study area is the lowest in the Gotjawal area. Seonheul Gotjawal is a wet forest where wetlands and caves have developed due to pahoehoe lava, and where Castanopsis sieboldii (Makino) Hatus. and Quercus acuta Thunb. are relatively abundant. The western Gotjawal is mostly distributed on aa lava that a dry environment is maintained due to its high permeability, and Quercus glauca Thunb. dominated and Arachniodes aristata (G. Forst.) Tindale inhabits widely. However, Subtropical Forest of Nabeup-ri is small in area but very well-conserved forest for a long time. Whereas the trees of Hangyeong Gotjawal were considered to have been frequently

Table 1. Comparison to the bryophyte species richness levels and liverwort indexes of evergreen broad-leaved forest of Cheongsu-ri at Hangyeong Gotjawal and other localities.

\begin{tabular}{|c|c|c|c|}
\hline Locality & Area $\left(\mathrm{km}^{2}\right)$ & No. of species & Liverwort index \\
\hline \multicolumn{4}{|l|}{ Gotjawal area } \\
\hline Evergreen broad-leaved forest of Cheongsu-ri (Hangyeong Gotjawal) & 0.501 & 72 & 23.6 \\
\hline Dongbaek-dongsan (Seonheul Gotjawal) & 1.420 & 85 & 27.0 \\
\hline Subtropical Forest of Nabeup-ri (Aewol Gotjawal) & 0.034 & 63 & 30.2 \\
\hline \multicolumn{4}{|l|}{ Mountain area } \\
\hline Sobaeksan Mt. & 322.011 & 236 & 41.9 \\
\hline Deogyusan Mt. & 232.000 & 311 & 40.8 \\
\hline Gayasan Mt. & 76.256 & 173 & 37.6 \\
\hline Taebaeksan Mt. & 17.440 & 144 & 29.2 \\
\hline
\end{tabular}


used by local residents in that they have small diameter at breast height and developed coppice shoots and branches. Therefore, we think that formation of patches that maintain bright and dry environment affects the composition and distribution of bryophytes. In the forest within study area, the mosses mainly occurred in sunny and dry habitats such as Racomitrium japonicum Dozy \& Molk., Ptychomitrium sinense (Mitt.) A. Jaeger, and Hypnum plumaeforme Wilson were confirmed. Since a floristic study of bryophytes of Korea has not been sufficiently conducted, it is difficult to compare and analyze the liverwort index data. Therefore, we suggest that more detailed studies on the bryophyte flora of Korea should be conducted at the regional scale.

\section{Remarkable species}

We think that Plagiochila furcifolia Mitt. (Bi-ja-nal-gae-ikki) inhabits in this area is worthy of special mention. This liverwort is distributed in Japan (Iwatsuki and Mizutani, 1972), China (So, 2001), India (Singh and Barbhuiya, 2012), and Vietnam (Shu et al., 2017). In Korea, this species was found from Bijarim Forest at Gujwa-Seongsan Gotjawal for the first time (Choi, 2013) and from Subtropical Forest of Nabeup-ri at Aewol Gotjawal for the secund time (Yim and Hyun, 2018). In case of Japan, this bryophyte species is categorized as 'near threatened species' in Hyogo Prefecture and as 'vulnerable species' in Osaka Prefecture (EnVision Conservation Office, 2018.). The species that its distributions of Korea are not known except Gotjawal area in Jejudo Island and the range of distribution is also narrow until now. However, it is hard to recognize this liverwort as species limitedly distributed in Jejudo Island and assess its rarity or conservation status. Because, in the case of Korea, the bryophyte flora is an unexplored field which has studied by a few researchers aiming mainly at Jejudo Island and not been investigated yet at a regional scale. Therefore, we suggest that a comprehensive research on the bryophyte flora of Korea should be conducted continuously.

\section{Life-forms}

We estimated the life-forms for each taxon in the study area and presented in the Table 2. Predominant life-form was weft (22 species, $30.6 \%$ ), followed by mat (18 spcies, $25.0 \%$ ), tall turf (15 species, 20.8\%), short turf and fan (5 species, 6.9\%, each of them), and tail and cushion ( 3 sepcies, $4.2 \%$, each of them). We analyzed the results based on the relationship between the adaptive strategy and life-form of bryophytes according to Kürschner (2004), Uyar et al. (2007), and Glime (2017). As a result, the rates of mostly pleurocarpous bryophytes (the life-forms of mat, weft, fan, and tail) dominating in mesic to hygric sites were $66.7 \%$, whereas mostly acrocarpous bryophytes (the life-forms of tall turf, short turf, cushion, and Annual) mainly observed in xeric habitats were $33.3 \%$ (Table 2, Appendix 1). These values indicate that the forests are widespread and dense in the study area. It is meaningful that the rates of bryophytes of mesic to hygric site type in this area are lower than in Dongbaek-dongsan (70.6\%) and Subtropical Forest of Nabeup-ri (76.2\%) and identical to the data of liverwort index (Yim et al., 2013; Yim and Hyun, 2018). These values supported that the subtropical forest of

Table. 2. The number of taxa and percentage composition according to the life-forms of bryophytes in the study area.

\begin{tabular}{lcc}
\hline \hline \multicolumn{1}{c}{ Life-forms } & No. of taxa & Percentage \\
\hline Xeric habitat type & 24 & 33.3 \\
Annuals & 1 & 1.4 \\
Cushions & 3 & 4.2 \\
Short turfs & 5 & 6.9 \\
Tall turfs & 15 & 20.8 \\
Mesic to hygric site type & 48 & 66.7 \\
Tails & 3 & 4.2 \\
Fans & 5 & 6.9 \\
Mats & 18 & 25.0 \\
Wefts & 22 & 30.6 \\
Total & 72 & 100.0 \\
\hline
\end{tabular}

Table 3. The number of taxa according to the substrate in the study area.

\begin{tabular}{lc}
\hline \hline \multicolumn{1}{c}{ Substrate } & No. of taxa \\
\hline Specific to only one substrate & 33 \\
Epilithic & 1 \\
Epiphytic & 1 \\
Epixylous & 8 \\
On the soil & \\
Common to two or more substrates & 15 \\
Epilithic and epiphytic & 3 \\
Epilithic and on the soil & 1 \\
Epilithic and epixylous & 1 \\
Epiphytic and epixylous & 2 \\
Epixylous and on the soil & 1 \\
Epilithic, epiphytic and epixylous & 2 \\
Epilithic, epiphytic and on the soil & 2 \\
Epilithic, epixylous and on the soil & 2 \\
Epilithic, epiphytic, epixylous and on the soil & 72 \\
Total &
\end{tabular}


Nabeup-ri and Dongbaek-dongsan are relatively more humid than the study area.

\section{Distribution pattern}

We estimated the substrates for each taxon to investigate the distribution pattern. The number of taxa according to the substrate are presented in the Table 3. Upon investigation into substrates, the bryophytes on the rocks were most diverse as 59 taxa followed by soil (19 taxa), decayed tree (10 taxa), and bark (22 taxa). The results seem to be caused by that the volcanic rock masses of various sizes lay scattered over the study area offering a lot of micro-habitats for bryophytes due to one of the characteristics of Gotjawal, where the rocks of various sizes are scattered randomly.

ORCID: Eun-Young YIM https://orcid.org/0000-0002-37334798; Byoung-Ki CHOI https://orcid.org/0000-0001-78721156; Hwa-Ja HYUN https://orcid.org/0000-0001-5971-7266

\section{Acknowledgments}

We wish to express our sincere thanks to two anonymous referees for their invaluable comments to improve the manuscript.

\section{Conflict of Interest}

The authors declare that there are no conflicts of interest.

\section{Literature Cited}

Cao, T., C. Gao, X. Li, D. Zhang, H. Si and D. H. Vitt. 2003. Moss Flora of China 3. Grimmiaceae through Tetraphidaceae. Science Press, Beijing and Missouri Botanical Garden Press, St. Louis, MO, $141 \mathrm{pp}$.

Choe, D. M. 1980. Illustrated Flora and Fauna of Korea Vol. 24. Musci, Hepaticae. Ministry of Education, Seoul, 790 pp. (in Korean)

Choi, S.-S. 2013. Taxonomy of the Liverworts and Hornworts in Korea. PhD dissertation, Jeonbuk National University, Jeonju. 118 pp. 604.

Choi, S.-S., V. A. Bakalin and B.-Y. Sun. 2010. The liverwort flora of Mt. Deogyu (Korea). In Bryoflora of the Russian Far East: Taxonomy, Genesis, Phytogeographic Relations. Vladivostok. Pp. 24-25.

Crandall-Stotler, B., R. E. Stotler and D. G. Long. 2009. Phylogeny and classification of the Marchantiophyta. Edinburgh Journal of Botany 66: 155-198.
EnVision Conservation Office. 2018. Search system of Japanese Red data. Retrieved Sep. 30, 2019, and available from http:// jpnrdb.com/index.html (in Japanese).

Gao, C., X. Li, T. Cao, B. Lin, D. H. Vitt and H. Si. 1999. Moss Flora of China 1. Science Press, Beijing and Missouri Botanical Garden Press, St. Louis, MO, 273 pp.

Glime, J. M. 2017. Adaptive strategies: growth and life forms. Chapt. 4-5. In Bryophyte Ecology. Vol. 1. 4-5-1 Physiological Ecology. Ebook sponsored by Michigan Technological University and the International Association of Bryologists. Glime, J. M. (ed.) Retrieved Sep. 30, 2019, available from http://digitalcommons.mtu.edu/bryophyte-ecology/.

Goffinet, B., W. R. Buck and A. J. Shaw. 2009. Morphology, anatomy, and classification of the Bryophyta. In Bryophyte Biology. Goffinet, B. and A. J. Shaw (eds.), Cambridge University Press, New York. Pp. 55-138.

Inoue, H. 1974. Illustrations of Japanese Hepaticae I. Tsukiji Shokan Publishing Co., Ltd., Tokyo, 189 pp. (in Japanese)

Inoue, H. 1976. Illustrations of Japanese Hepaticae II. Tsukiji Shokan Publishing Co., Ltd., Tokyo. 193 pp. (in Japanese)

Iwatsuki, Z. 2001. Mosses and Liverworts of Japan. Heibonsha Ltd., Tokyo, 355 pp. (in Japanese)

Iwatsuki, Z. and M. Mizutani. 1972. Colored Illustration of the Bryophytes of Japan. Hoikusha, Osaka, 405 pp. (in Japanese)

Jeju Special Self-Governing Province. 1997. General Investigation Report on Mid-Mountain Area of Jeju Island. Jeju Special Self-Governing Province, Jeju, 344 pp. (in Korean).

Jeju Special Self-Governing Province. 2009. Jeju Dialect Dictionary. Jeju Special Self-Governing Province, Jeju, 730 pp. (in Korean)

Jeon Y., U. S. Ahn, C. G. Ryu, S. S. Kang and S. T. Song. 2012. A review of geological characteristics of Gotjawal terrain in Jeju Island: preliminary study. Journal of the Geological Society of Korea 48: 425-434. (in Korean)

Jeon Y. M., D. S. Kim, J. S. Ki and J. G. Koh. 2015. A proposal for geological classification of Gotjawal terrain in Jeju Island and its meaning. Journal of the Geological Society of Korea 51: 235-241. (in Korean)

Jeong, K. J. 2012. A study on perception and use of Gotjawal in Jeju Island. Journal of the Association of Korean Photo-Geographers 22:11-28. (in Korean)

Jeong, K. J. 2015. The past, present and future of Gotjawal: questions and proposals about the existence of Gotjawal. Journal of the association of Korean Photo-Geographers 25: 15-32. (in Korean)

Jeong, K. J., S. G. Kang, H. S. Choi and C. S. Kim. 2013. A study on charcoal production activities at Seonheul Gotzawal in Jeju Island. Journal of the Association of Korean Photo-Geogra- 
phers 23: 37-55. (in Korean)

Kang, H.- G., C.-S. Kim and E.-S. Kim. 2013. Human influence, regeneration, and conservation of the Gotjawal forests in Jeju Island, Korea. Journal of Marine and Island Cultures 2: 85-92.

Kürschner, H. 2004. Life strategies and adaptations in bryophytes from the Near and Middle East. Turkish Journal of Botony 28: 73-84.

Li, X., Z. Li, B. Lin, T. Cao, C. Gao, H. Si, D. G. Horton, Z. Iwatsuki, W. D. Reese, and D. H. Vitt. 2001. Moss Flora of China 2. Science Press, Beijing and Missouri Botanical Garden Press, St. Louis, MO, 283 pp.

Mägdefrau, K. 1982. Life-forms of bryophytes. In Bryophyte Ecology. Smith, A. J. E. (ed.), Chapman and Hall, London. Pp. 45-58.

Moon, M.-O., J.-H. Tho, C. H. Kim, C.-S. Kim and M.-H. Kim. 2006. Unrecorded species from Korean flora: Maesa japonica (Thunb.) Moritzi \& Zoll. [Maesaceae] and Cardamine tanakae Franch. \& Sav. [Brassicaceae]. Korean Journal of Plant Taxonomy 36: 153-161. (in Korean)

Nakanishi, K. 2001. Floristic diversity of bryophyte vegetation in relation to island area. The Journal of the Hattori Botanical Laboratory 91: 301-316.

Noguchi, A. 1987. Illustrated Moss Flora of Japan 1. Daigaku Printing Co., Ltd., Hiroshima. Pp. 2-242.

Noguchi, A. 1988. Illustrated Moss Flora of Japan 2. Daigaku Printing Co., Ltd., Hiroshima. Pp. 243-491.

Noguchi, A. 1989. Illustrated Moss Flora of Japan 3. Daigaku Printing Co., Ltd., Hiroshima. Pp. 493-742.

Noguchi, A. 1991. Illustrated Moss Flora of Japan 4. Daigaku Printing Co., Ltd., Hiroshima. Pp. 743-1012.

Noguchi, A. 1994. Illustrated Moss Flora of Japan 5. Daigaku Printing Co., Ltd., Hiroshima. Pp. 1013-1253.

Papp, B. 2008. Contributions to the Bryophyte Flora of the Mt. Taebaek, South Korea. Studia Botanica Hungarica 39: 89-100.

Shu, L., Y. L. Xiang, X. F. Cheng, Y. M. Wei, J. Wang, L. N. Zhang, W. Li, X. B. Yin, W. P. Zhang, C. X. Zhao, T. Peng, T. V. Do, T. N. Lu and R. L. Zhu. 2017. New liverwort and hornwort records for Vietnam. Cryptogamie. Bryologie 38: 411445.
Sin, Y. S. 2016a. 2016 Natural Resources Survey of Gayasan National Park. National Park Research Institute, Korea National Park Service, Wonju, 674 pp. (in Korean)

Sin, Y. S. 2016b. 2016 Natural Resources Survey of Sobaeksan National Park. National Park Research Institute, Korea National Park Service, Wonju, 788 pp. (in Korean)

Singh, S. K. and H. A. Barbhuiya. 2012. A Compendium to Marchantiophyta and Anthocerotophyta of Assam, India. Archive for Bryology 149: 1-30.

So, M. L. 2001. Plagiochila (Hepaticae: Plagiochilaceae) in China. Systematic Botany Monographs 60: 1-214.

Song, S. T. 2000. Distribution and lithology of the Aa rubble flows in Cheju Island, Korea. PhD dissertation, Pusan National University, Busan, 118 pp. (in Korean)

Song, S. T. 2003a. Lavas in Gotjawal terrain, Jeju Island, Korea: No. 3. Doneori Gotjawal lava. Journal of Basic Science, Jeju National University 16: 47-55. (in Korean)

Song, S. T. 2003b. Lavas in Gotjawal terrain, Jeju Island, Korea: No. 4. Byeongak Gotjawal lava. Journal of Basic Science, Jeju National University 16: 57-63. (in Korean)

Uyar, G., M. Alatas, M. Oren and T. Kecell. 2007. The Bryophyte Flora of Yenice Forests (Karabük, Turkey). International Journal of Botany 3: 129-146.

Wu, P., B. Lin, C. Gao, T. Cao, Z. Li, B. C. Tan, H. Si, Y. Jia, M. Wang, X. Fu, J. Sun and B. Zhong. 2002. Moss Flora of China 6. Science Press, Beijing and Missouri Botanical Garden Press., St. Louis, MO, 221 pp.

Yim, E. Y. and H.-J. Hyun. 2018. Floristic study of bryophytes in a subtropical forest of Nabeup-ri at Aewol Gotjawal, Jejudo Island. Korean Journal of Plant Taxonomy 48: 100-108.

Yim, E.-Y., M.-O. Moon, B.-Y. Sun and K. Nakanishi. 2013. Floristics of bryophytes in Dongbaek-dongsan at Seonheul Gotjawal. Korean Journal of Plant Taxonomy 43: 274-284.

Yoon, Y. J., C. H. Kim, K. V. Gorobets and B.-Y. Sun. 2011. The moss flora of Mt. Deogyu in Korea. Korean Journal of Plant Taxonomy 41: 287-297.

Yoon, Y. T. 2014. A humanities reflection on Got, Jawal and Gotjawal forest. Journal of Cheju Studies 41: 27-59. (in Korean) 
Appendix 1. Floristic list of the evergreen broad-leaved forest of Cheongsu-ri at Hangyeong Gotjawal in Korea.

\begin{tabular}{|c|c|c|c|c|}
\hline Taxa & Korean name & $\begin{array}{l}\text { Life } \\
\text {-form }\end{array}$ & Substrate & $\begin{array}{c}\text { Voucher No. } \\
\text { (Eun-Young Yim-) }\end{array}$ \\
\hline \multicolumn{5}{|l|}{ Bryophyta Schimp. 선류식물문 } \\
\hline \multicolumn{5}{|l|}{ Polytrichaceae Schwägr. 솔이끼과 } \\
\hline Atrichum undulatum (Hedw.) P. Beauv. & 주름솔이끼 & Tall turfs & $\mathrm{L}$ & SYG006 \\
\hline Pogonatum inflexum (Lindb.) Sande Lac. & 아기들솔이끼 & Tall turfs & $\mathrm{S}$ & SYG062 \\
\hline \multicolumn{5}{|l|}{ Funariaceae Schwägr. 표주박이끼과 } \\
\hline Physcomitrium sphaericum (C. Ludw.) Fürnr. & 아기풍경이끼 & Short turfs & $\mathrm{L}$ & SYG085 \\
\hline \multicolumn{5}{|l|}{ Grimmiaceae Arn. 고깔바위이끼과 } \\
\hline Grimmia pilifera P. Beauv. & 흰털고깔바위이끼 & Cushions & $\mathrm{L}$ & SYG049 \\
\hline Racomitrium japonicum Dozy \& Molk. & 늦은서리이끼 & Tall turfs & $\mathrm{S}$ & SYG198 \\
\hline \multicolumn{5}{|l|}{ Fissidentaceae Schimp. 봉황이끼과 } \\
\hline Fissidens dubius P. Beauv. & 벼슬봉황이끼 & Tall turfs & $\mathrm{L}$ & SYG328 \\
\hline Fissidens gymnogynus Besch. & 작은봉황이끼 & Tall turfs & $\mathrm{L}$ & SYG030 \\
\hline \multicolumn{5}{|l|}{ Ptychomitriaceae Schimp. 곱슬이끼과 } \\
\hline Ptychomitrium dentatum (Mitt.) A. Jaeger & 물가곱슬이끼 & Cushions & $\mathrm{L}$ & SYG069 \\
\hline Ptychomitrium sinense (Mitt.) A. Jaeger & 곱슬이끼 & Cushions & $\mathrm{L}$ & SYG070 \\
\hline \multicolumn{5}{|l|}{ Ditrichaceae Limpr. 금실이끼과 } \\
\hline Ditrichum pallidum (Hedw.) Hampe & 금실이끼 & Short turfs & $\mathrm{S}$ & SYG109 \\
\hline \multicolumn{5}{|l|}{ Pottiaceae Hampe 꼬마이끼과 } \\
\hline Weissia controversa Hedw. & 꼬마이끼 & Short turfs & $\mathrm{S}$ & SYG110 \\
\hline \multicolumn{5}{|l|}{ Bryaceae Schwägr. 은이끼과 } \\
\hline Brachymenium nepalense var. clavulum (Mitt.) Ochi & 아기노란참외이끼 & Short turfs & LP & SYG012 \\
\hline Pohlia longicollis (Hedw.) Lindb. & 긴목수세미이끼 & Tall turfs & $\mathrm{S}$ & SYG074 \\
\hline Rosulabryum capillare (Hedw.) J.R. Spence & 철사이끼 & Short turfs & $\mathrm{L}$ & SYG011 \\
\hline \multicolumn{5}{|l|}{ Mniaceae Schwägr. 참이끼과 } \\
\hline Mnium ambiguum $\mathrm{H}$. Müll. & 납작맥초롱이끼 & Tall turfs & $\mathrm{L}$ & SYG311 \\
\hline Plagiomnium acutum (Lindb.) T. J. Kop. & 아기들덩굴초롱이끼 & Tall turfs & LS & SYG159 \\
\hline Trachycystis microphylla (Dozy \& Molk.) Lindb. & 아기초롱이끼 & Tall turfs & LP & SYG134 \\
\hline \multicolumn{5}{|l|}{ Bartramiaceae Schwägr. 구슬이끼과 } \\
\hline Philonotis thwaitesii Mitt. & 아기물가이끼 & Tall turfs & $\mathrm{L}$ & SYG089 \\
\hline Philonotis turneriana (Schwägr.) Mitt. & 큰물가이끼 & Tall turfs & $\mathrm{L}$ & SYG080 \\
\hline \multicolumn{5}{|l|}{ Hedwigiaceae Schimp. 톳이끼과 } \\
\hline Hedwigia ciliata (Hedw.) P. Beauv. & 톳이끼 & Tall turfs & $\mathrm{L}$ & SYG015 \\
\hline \multicolumn{5}{|l|}{ Thuidiaceae Schimp. 깃털이끼과 } \\
\hline Anomodon viticulosus (Hedw.) Hook. \& & 굽은명주실이끼 & Tails & $\mathrm{L}$ & SYG019 \\
\hline Claopodium aciculum (Broth.) Broth. & 가시이끼 & Wefts & $\mathrm{L}$ & SYG052 \\
\hline Haplocladium angustifolium (Hampe \& Müll. Hal.) Broth. & 침작은명주실이끼 & Wefts & LPXS & SYG154 \\
\hline Haplocladium microphyllum (Hedw.) Broth. & 작은명주실이끼 & Wefts & LP & SYG142 \\
\hline Haplohymenium pseudotriste (Müll. Hal.) Broth. & 꼬마바위실이끼 & Wefts & LP & SYG120 \\
\hline Herpetineuron toccoae (Sull. \& Lesq.) Cardot & 나선이끼 & Tails & LP & SYG199 \\
\hline
\end{tabular}


Appendix 1. Continued.

\begin{tabular}{|c|c|c|c|c|}
\hline Taxa & Korean name & $\begin{array}{l}\text { Life } \\
\text {-form }\end{array}$ & Substrate & $\begin{array}{c}\text { Voucher No. } \\
\text { (Eun-Young Yim-) }\end{array}$ \\
\hline Hylocomiopsis ovicarpa (Besch.) Cardot & 아기호랑꼬리이끼 & Wefts & $\mathrm{L}$ & SYG038 \\
\hline Pelekium versicolor (Hornsch. ex Müll. Hal.) Touw & 아기깃털이끼 & Wefts & LPXS & SYG119 \\
\hline Thuidium cymbifolium (Dozy \& Molk.) Dozy \& Molk. & 물가깃털이끼 & Wefts & $\mathrm{L}$ & SYG076 \\
\hline Thuidium kanedae Sakurai & 깃털이끼 & Wefts & LS & SYG124 \\
\hline \multicolumn{5}{|l|}{ Brachytheciaceae Schimp. 양털이끼과 } \\
\hline Brachythecium brotheri Paris & 큰양털이끼 & Wefts & $\mathrm{L}$ & SYG104 \\
\hline Brachythecium buchananii (Hook.) A. Jaeger & 긴양털이끼 & Wefts & $\mathrm{L}$ & SYG098 \\
\hline Brachythecium plumosum (Hedw.) Schimp. & 날개양털이끼 & Wefts & LP & SYG184 \\
\hline Brachythecium populeum (Hedw.) Schimp. & 양털이끼 & Wefts & LXS & SYG138 \\
\hline Bryhnia novae-angliae (Sull. \& Lesq.) Grout & 세모양털이끼 & Wefts & $\mathrm{L}$ & SYG267 \\
\hline Cirriphyllum piliferum (Hedw.) Grout & 겉근양털이끼 & Wefts & $\mathrm{L}$ & SYG274 \\
\hline Eurhynchium savatieri Schimp. ex Besch. & 가는부리이끼 & Wefts & LPS & SYG139 \\
\hline Rhynchostegium pallidifolium (Mitt.) A. Jaeger & 아기양털부리이끼 & Wefts & LP & SYG227 \\
\hline \multicolumn{5}{|l|}{ Hypnaceae Schimp. 털깃털이끼과 } \\
\hline Homomallium connexum (Cardot) Broth. & 쌍끝양털이끼 & Wefts & PX & SYG230 \\
\hline Hурпит oldhamii (Mitt.) A. Jaeger & 가는털깃털이끼 & Wefts & $\mathrm{L}$ & SYG055 \\
\hline Hypnum plumaeforme Wilson & 털깃털이끼 & Wefts & XS & SYG394 \\
\hline Isopterygium minutirameum (Müll. Hal.) A. Jaeger & 겉주목이끼 & Wefts & $\mathrm{L}$ & SYG122 \\
\hline Pseudotaxiphyllum pohliaecarpum (Sull. \& Lesq.) Z. Iwats. & 빨간겉주목이끼 & Mats & LS & SYG354 \\
\hline Pylaisiadelpha tenuirostris (Bruch \& Schimp. ex Sull.) W. R. Buck & 무성아실이끼 & Mats & $\mathrm{P}$ & SYG017 \\
\hline Taxiphyllum taxirameum (Mitt.) M. Fleisch. & 주목이끼 & Mats & LPX & SYG004 \\
\hline \multicolumn{5}{|l|}{ Plagiotheciaceae M. Fleisch. 산주목이끼과 } \\
\hline Plagiothecium nemorale (Mitt.) A. Jaeger & 산주목이끼 & Mats & LP & SYG128 \\
\hline \multicolumn{5}{|l|}{ Entodontaceae Kindb. 윤이끼과 } \\
\hline Entodon challengeri (Paris) Cardot & 넓은잎윤이끼 & Wefts & $\mathrm{L}$ & SYG061 \\
\hline Entodon sullivantii (Müll. Hal.) Lindb. & 가는윤이끼 & Wefts & LXS & SYG151 \\
\hline \multicolumn{5}{|l|}{ Sematophyllaceae Broth. 나무실이끼과 } \\
\hline Sematophyllum subhumile (Müll. Hal.) M. Fleisch. & 나무실이끼 & Mats & $\mathrm{X}$ & SYG022 \\
\hline \multicolumn{5}{|l|}{ Neckeraceae Schimp. 납작이끼과 } \\
\hline Homalia japonica Besch. & 꼬리윤납작이끼 & Fans & $\mathrm{L}$ & SYG078 \\
\hline Homalia trichomanoides (Hedw.) Schimp. & 윤납작이끼 & Fans & LP & SYG079 \\
\hline Neckeropsis nitidula (Mitt.) M. Fleisch. & 리본납작이끼 & Fans & LP & SYG130 \\
\hline Pseudanomodon giraldii (Müll. Hal.) Ignatov \& Fedosov & 큰명주실이끼 & Tails & $\mathrm{L}$ & SYG029 \\
\hline Thamnobryum plicatulum (Sande Lac.) Z. Iwats. & 그늘대호꼬리이끼 & Fans & $\mathrm{L}$ & SYG135 \\
\hline Thamnobryum subseriatum (Mitt. ex Sande Lac.) B. C. Tan & 대호꼬리이끼 & Fans & XS & SYG003 \\
\hline \multicolumn{5}{|l|}{ Marchantiophyta Stotler \& Crand. -Stotl. 태류식물문 } \\
\hline \multicolumn{5}{|l|}{ Marchantiaceae Lindl. 우산이끼과 } \\
\hline Marchantia polymorpha $\mathrm{L}$. & 우산이끼 & Mats & S & SYG090 \\
\hline Aytoniaceae Cavers 삿갓우산이끼과 & & & & \\
\hline
\end{tabular}


Appendix 1. Continued.

\begin{tabular}{|c|c|c|c|c|}
\hline Taxa & Korean name & $\begin{array}{c}\text { Life } \\
\text {-form }\end{array}$ & Substrate & $\begin{array}{c}\text { Voucher No. } \\
\text { (Eun-Young Yim-) }\end{array}$ \\
\hline Reboulia hemisphaerica (L.) Raddi & 삿갓우산이끼 & Mats & $\mathrm{S}$ & SYG097 \\
\hline \multicolumn{5}{|c|}{ Conocephalaceae Müll. Frib. ex Grolle 패랭이우산이끼과 } \\
\hline Conocephalum conicum (L.) Dumort. & 패랭이우산이끼 & Mats & $\mathrm{L}$ & SYG091 \\
\hline \multicolumn{5}{|l|}{ Ricciaceae Rchb. 밭둥근이끼과 } \\
\hline Riccia fluitans $\mathrm{L}$. & 물긴가지이끼 & Annuals & $\mathrm{S}$ & SYG415 \\
\hline \multicolumn{5}{|l|}{ Metzgeriaceae H. Klinggr. 리본이끼과 } \\
\hline Metzgeria lindbergii Schiffn. & 리본이끼 & Mats & LP & SYG118 \\
\hline \multicolumn{5}{|l|}{ Porellaceae Cavers 세줄이끼과 } \\
\hline Porella ulophylla (Steph.) S. Hatt. & 주름세줄이끼 & Mats & LX & SYG180 \\
\hline Porella vernicosa Lindb. & 가시세줄이끼 & Mats & $\mathrm{L}$ & SYG157 \\
\hline \multicolumn{5}{|l|}{ Radulaceae Müll. Frib. 부채이끼과 } \\
\hline Radula japonica Gottsche ex Steph. & 부채이끼 & Mats & LP & SYG178 \\
\hline \multicolumn{5}{|l|}{ Frullaniaceae Lorch 지네이끼과 } \\
\hline Frullania ericoides (Nees) Mont. & 초록지네이끼 & Mats & LP & SYG028 \\
\hline \multicolumn{5}{|l|}{ Lejeuneaceae Cavers 작은귀이끼과 } \\
\hline Lejeunea japonica Mitt. & 작은귀이끼 & Mats & LPS & SYG156 \\
\hline Trocholejeunea sandvicensis (Gottsche) Mizut. & 둥근귀이끼 & Mats & LP & SYG027 \\
\hline \multicolumn{5}{|c|}{ Lophocoleaceae Müll. Frib. ex Vanden Berghen 두끝벼슬이끼과 } \\
\hline Heteroscyphus argutus (Nees) Schiffn. & 아기비늘이끼 & Mats & $\mathrm{L}$ & SYG126 \\
\hline Heteroscyphus planus (Mitt.) Schiffn. & 비늘이끼 & Mats & LP & SYG132 \\
\hline Lophocolea heterophylla (Schrad.) Dumort. & 두끝벼슬이끼 & Mats & $\mathrm{L}$ & SYG127 \\
\hline \multicolumn{5}{|l|}{ Plagiochilaceae Müll. Frib. 날개이끼과 } \\
\hline Plagiochila furcifolia Mitt. & 비자날개이끼 & Tall turfs & $\mathrm{L}$ & SYG121 \\
\hline Plagiochila ovalifolia Mitt. & 둥근날개이끼 & Tall turfs & $\mathrm{L}$ & SYG117 \\
\hline Plagiochila sciophila Nees ex Lindenb. & 아기날개이끼 & Tall turfs & $\mathrm{L}$ & SYG141 \\
\hline
\end{tabular}

L, epilithic; P, epiphytic; X, epixylous; S, on the soil. 